\title{
Pengaruh Pendidikan Kewirausahaan Dan Motivasi Terhadap Minat Berwirausaha Mahasiswa Universitas Lancang Kuning
}

\author{
NURMANSYAH \\ Dosen Tetap Fakultas Ekonomi Universitas Lancang Kuning \\ Jln. Yos Sudarso KM 8 Rumbai \\ E-mail : nurmansyahsr@gmail.com
}

\begin{abstract}
Topic this research is The Impact Entrepreneurship Education and motivation to entrepreneurship interest student of Lancang Kuning University. The problem needed to be solved in this study was whether Entrepreneurship Education and motivation impact the Interest in entrepreneurship student of Lancang Kuning University. This study held in order to know and analyze the effect of education entrepreneurship and motivation to entrepreneurship interest student of Lancang Kuning University. Variables used were Entrepreneurship Interset as dependent while entrepreneurship education and motivation as independent. Population were 13.342 student of Lancang Kuning University. Samples determined by using Slovin formulation that concisted of 100 student who were selected by using convenience sampling method. Hyphotesis test were conducted by using multiple linier regression analysis that assisted with SPSS program. Study revealed that student of Lancang Kuning University is everagely had possessed very high level of entrepreneurship interest as the result of strong education entrepreneurship and motivation characteristics. Result this research as Entrepreneurship Education the influence to Entrepreneur interest is $45 \%$, meanwhile motivation the influence to Entrepreneur interest $31,60 \%$, and The influence of Entrepreneurship Education the influence to Entrepreneur interest and motivation is significant amount $35,80 \%$. So that, either education entrepreneurship and motivation positively and significantly influence to entrepreneurship interest student of Lancang Kuning University
\end{abstract}

Keywords: Entrepreneurship Education, Motivation, Entrepreneurship Interest Student.

Perkembangan pelaku usaha kecil dan menengah (UKM) di Indonesia masih dikatakan kecil hanya sebesar 1,69\% dari jumlah penduduk di Indonesia. Bila dibandingkan dengan negara tetangga Singapura $7 \%$, Malaysia $5 \%$, Thailand $4 \%$, Indonesia $1,69 \%$. Negara maju AS dan Jepang memiliki jumlah pengusaha lebih dari $10-11 \%$ dari jumlah penduduknya. Kemenkop UKM menyatakan bahwa jumlah wirausahawan di Indonesia melonjak tajam dari 0,24\% menjadi $1,56 \%$ dan pada tahun 2016 menjadi 1,69 \% dari jumlah penduduk. Jumlah wirausaha Indonesia masih kalah jumlah dibandingkan dengan negara tetangga.

Meskipun jumlah pengusaha Indonesia masih sangat minim, namun Survey yang dilakukan oleh Global Entrepreneurship Monitor (GEM) pada tahun 2013 menunjukkan bahwa keinginan berwirausaha masyarakat Indonesia adalah yang kedua tertinggi di ASEAN setelah Filipina. Bila jumlah wirausaha dapat bertambah maka akan dapat meningkatkan ekonomi negara, bertambah lapangan pekerjaan, dan akhirnya dapat meningkatkan kualitas kesejahteraan masyarakat.

Pendidikan

kewirausahaan (entrepreneurship) harus ditingkatkan dan didorong di Perguruan Tinggi, agar lulusannya mampu mandiri. Pendidikan di Perguruan Tinggi diharapkan dapat menyiapkan mahasiswa untuk berani mandiri, tidak lagi terfokus menjadi pencari kerja. Apalagi data pengangguran terdidik di Indonesia menunjukkan, semakin tinggi pendidikan seseorang, semakin rendah kemandirian dan semangat kewirausahaannya. 
Bagi sarjana yang telah mendapatkan pekerjaanpun, nasib mereka masih terancam dengan PHK yang membuat pekerjaan tidak aman (job unsecurity), mengingat kondisi perekonomian Indonesia yang masih belum bangkit dari keterpurukan. Krisis global yang menginduk kepada kapitalisme berimbas juga pada tingkat pengangguran di Indonesia.

Pendidikan kewirausahaan perlu dilakukan untuk mengatasi pengangguran terdidik yang terus meningkat dengan menyiapkan lulusan perguruan tinggi yang tidak hanya berorientasi sebagai pencari kerja, tetapi juga sebagai pencipta lapangan pekerjaan. Saat ini sebanyak $82,2 \%$ lulusan perguruan tinggi bekerja sebagai pegawai. Masa tunggu lulusan perguruan tinggi untuk mendapatkan pekerjaan antara 6 bulan sampai 3 tahun.

Tingginya jumlah pengangguran berpendidikan tinggi menunjukkan bahwa proses pendidikan di perguruan tinggi kurang menyentuh persoalan-persoalan nyata didalam masyarakat. Perguruan tinggi belum dapat menghasilkan lulusan yang mampu berkreasi di dalam keterbatasan.

Dengan gencarnya pendidikan kewirausahaan baik yag diintegrasikan dalam kurikulum maupun kegiatan kemahasiswaan diharapkan dapat meningkatkan jumlah wirausaha dari mahasiswa, khususnya alumni dari Universitas Lancang Kuning.

Pendidikan kewirausahaan harus berjalan secara berkesinambungan dan menjadi bagian yang tidak terpisahkan dari seluruh proses pendidikan di perguruan tinggi. Seluruh Fakultas dilingkungan Universitas Lancang Kuning memberikan matakuliah Kewirausahaan I tentang teori, dan Kewirausahaan II Tentang Praktek, dengan melakukan pemagangan, atau memberikan pelatihan, dan setelah pelatihan diberikan bantuan dana agar mereka dapat mempraktekkan pengetahuan dan pengalamannya yang telah diperoleh. : misalnya memberikan pelatihan membuat sablon, dan diberikan bantuan dana untuk membeli bahan dan membuat sablonnya.

Peranan perguruan tinggi dalam memotivasi mahasiswanya menjadi wirausahawan muda sangatlah penting. Hal ini dilihat dari beberapa pembahasan bidang kewirausahaan yang telah dikemukakan diatas. Masalahnya adalah bagaimana pihak perguruan tinggi mampu melakukan peranannya dengan benar dan mampu menghasilkan sarjana yang siap berwirausaha. Peranan pihak perguruan tinggi dalam menyediakan suatu wadah yang memberikan kesempatan memulai usaha sejak masa kuliah sangatlah penting, sesuai dengan pendapat Thomas Zimmerer bahwa memulai bisnis, bisa pada saat masa kuliah berjalan, akan tetapi yang lebih penting adalah bagaimana peranan perguruan tinggi dalam hal memotivasi mahasiswanya untuk tergabung dalam wadah tersebut. Karena tanpa memberikan gambaran secara jelas apa saja manfaat berwirausaha, maka besar kemungkinan para mahasiswa tidak ada yang termotivasi untuk memperdalam keterampilan berbisnisnya.

Oleh karena itu, pihak perguruan tinggi juga perlu mengetahui faktor yang paling dominan memotivasi mahasiswa dalam berwirausaha. Hasil penelitian mengatakan bahwa ada 3 faktor paling dominan dalam memotivasi sarjana menjadi wirausahawan yaitu faktor kesempatan, faktor kebebasan, faktor kepuasan hidup. Ketiga faktor itulah yang membuat mereka menjadi wirausahawan. Tulisan ini sangat membantu pihak perguruan tinggi dalam memberikan informasi kepada para mahasiswanya, bahwa menjadi wirausahawan akan mendapatkan beberapa kesempatan, kebebasan dan kepuasan hidup. Proses penyampaian ini harus sering dilakukan sehingga mahasiswa semakin termotivasi untuk memulai berwirausaha. Sebab banyak mahasiswa merasa takut menghadapi risiko bisnis yang mungkin 
muncul yang membuat mereka membatalkan rencana bisnis sejak dini.

Motivasi yang semakin besar kepada mahasiswa menyebabkan wadah yang disiapkan oleh pihak perguruan tinggi tidak sia-sia, melainkan akan melahirkan wirausahawan muda yang handal. Dengan semakin banyaknya mahasiswa memulai usaha sejak masa kuliah, maka besar kemungkinan setelah lulus akan melanjutkan usaha yang sudah dirintisnya. Sehingga semakin berkurangnya jumlah pengangguran di negara kita, akan tetapi sebaliknya semakin bertambahnya jumlah lapangan pekerjaan yang dibuka.

Dari itu universitas Lancang Kuning harus dapat membuat program bagaimana mempersiapkan mahasiswa menjadi wirausaha yang sukses bila selesai kuliah. Dalam penelitian ini menguji apakah Pendidikan Kewirausahaan dan motivasi secara parsial maupun secara simultan berpengaruh terhadap minat mahasiswa Universitas Lancang Kuning untuk menjadi wirausaha .

Fenomena rendahnya minat dan motivasi mahasiswa untuk berwirausaha saat ini menjadi pemikiran serius berbagai pihak, baik pemerintah, dunia pendidikan, dan masyarakat. Berbagai upaya telah dilakukan oleh berbaga pihak untuk menumbuhkan jiwa kewirausahaan terutama merubah cara berpikir mahasiswa yang selama ini hanya berminat sebagai pencari kerja (job seeker), tidak sebagai pencipta lapangan kerja (job maker) baik bagi dirinya sendiri maupun untuk orang lain. Adi Susanto (2005) menyatakan beberapa faktor yang memotivasi seseorang untuk menjadi entrepreneur yaitu keinginan merasakan pekerjaan bebas, keberhasilan diri yang dicapai, dan toleransi akan adanya risiko. Dalam penelitian ini variabel motivasi menggunakan dimensi / indikator dari McClelland terdiri dari Motivasi berprestasi, motivasi berafiliasi, motivasi kekuatan. Hasil penelitian McClelland menunjukkan bahwa individu yang mempunyai motivasi untuk berprestasi yang tinggi cenderung untuk memilih profesi bisnis atau usaha dan berpengaruh terhadap perkembangan usahanya (Nurmansyah, 2011:141).

Pendidikan kewirausahaan dapat membentuk pola pikir, sikap , dan perilaku pada mahasiswa untuk menjadi seorang wirausaha sehingga mereka dapat memilih berwirausaha sebagai pilihan karir. Pengaruh tersebut perlu dikaji lebih lanjut apakah dengan adanya mata kuliah kewirausahaan dapat menimbulkan minat berwirausaha mahasiswa. Penelitian ini mencoba untuk mengetahui : apakah pendidikan Kewirausahaan yang sudah dilaksanakan di Lingkungan Universitas Lancang Kuning dan motivasi dapat mempengaruhi Minat mahasiswa untuk berwirausaha.

Kewirausahaan adalah kemampuan kreatif dan inovatif untuk mencari peluang menuju sukses. Kewirausahaan adalah ilmu yang mempelajari tentang nilai, kemampuan dan perilaku dalam menghadapi tantangan hidup.

Inti dari kewirausahaan adalah kemampuan untuk menciptakan sesuatu yang baru dan berbeda melalui berpikir kreatif dan bertindak inovatif untuk menciptakan peluang. Banyak orang yang berhasil dan sukses karena memiliki kemampuan berpikir kreatif dan inovatif. Proses kreatif dan inovatif timbul dengan memunculkan ide-ide dan pemikiran baru untuk menciptakan sesuatu yang baru dan berbeda.

Kewirausahaan merupakan kemampuan dalam menciptakan nilai tambah melalui proses pengelolaan sumber daya dengan cara baru dan berbeda, melalui : 1. Pengembangan teknologi baru, 2. Penemuan pengetahuan ilmiah baru, 3. Perbaikan produk dan jasa yang ada, 4 . Penemuan cara baru untuk menghasilkan produk lebih banyak dengan penggunaan sumberdaya yang lebih efisien.

Kreativitas adalah kemampuan untuk mengembangkan ide-ide baru dan cara-cara baru dalam memecahkan masalah dan menemukan peluang, dengan kata lain

p.ISSN: $2407-800 X \quad$ e.ISSN: 2541-4356 
kreativitas adalah kemampuan untuk memikirkan sesuatu yang baru dan berbeda

Inovasi adalah kemampuan untuk menerapkan kreativitas untuk memecahkan masalah dan menemukan peluang, dengan perkataan lain inovasi adalah kemampuan untuk melakukan sesuatu yang baru dan berbeda.

Zimmerer dalam (Suryana 2006) Sukses kewirausahaan dapat tercapai dengan melakukan sesuatu yang lama dengan caracara baru. Kasmir (2006 : 33) menyatakan bahwa berdasarkan hasil penelitian terdapat beragam cara memulai usaha. Ada lima sebab seseorang mulai merintis usahanya,yaitu : 1. Faktor keluarga, 2. Sengaja terjun menjadi pengusaha, 3. Kerja sampingan (iseng), 4. Coba-coba, 5. Terpaksa.

Selanjutnya Kasmir (2006:37) menyatakan bahwa bidang Usaha yang digeluti oleh seseorang tergantung pada empat faktor, yaitu : 1. Minat atau bakat, 2. Modal, 3. Waktu, 4. Laba, 5. Pengalaman.

Mahasiswa sebagai salah satu golongan elit di masyarakat yang diharapkan menjadi pemimpin bangsa di masa depan, dan diharapkan dapat menjadi pelopor dalam mengembangkan semangat kewirausahaan.

Adi Susanto (2006) menyatakan ada beberapa faktor yang memotivasi seseorang untuk menjadi entrepreneur yaitu keinginan merasakan pekerjaan bebas, keberhasilan diri yang dicapai, dan toleransi akan adanya risiko.

Sergal, Borgia, dan Schoenfeld (2005) mentakan bahwa toleransi akan risiko, keberhasilan diri dalam berwirausaha, dan kebebasan dalam bekerja memiliki pengaruh positif terhadap minat mahasiswa.

Dalam penelitian lain Rano Aditya Putra (2012) dengan judul : Faktor Faktor Penentu MinatMahasiswa Manajemen Untuk Berusaha (Studi Mahasiswa Manajemen FE Universitas Negeri Padang). Dalam penelitian tersebut ditemukan bahwa faktor penentu minat mahasiswa berusaha adalah 1 . Faktor lingkungan, 2. faktor harga diri, 3. Faktor peluang, 4. Faktor kepribadian, 5.
Faktor visi, 6 faktor pendapatan dan percaya diri.

Suryana (2006: 20) menyatakan bahwa karakteristik Kewirausahaan adalah : 1. Percaya diri , 2. Berorientasi pada hasil, 3. Berani mengambil risiko, 3. Memi-liki jiwa kepemimpinan (berani tampil berbeda), 4. Berorientasi pada masa depan

Pendidikan adalah suatu kegiatan untuk memperbaiki kemampuan seorang dengan meningkatkan pengetahuan umum termasuk peningkatan penguasaan teori dan keterampilan dalam pengambilan keputusan untuk menghadapi persoalan-persoalan atau masalah-masalah organisasi atau perusahaan (Nurmansyah, 2011 : 94).

Pendidikan Kewirausahaan yang dimaksudkan adalah proses pembelajaran untuk mengubah sikap dan pola pikir mahasiswa terhadap pilihan karier berwirausaha. Dengan demikian mahasiswa yang telah menempuh mata kuliah Kewirausahaan akan memiliki nilai-nilai hakiki dan karakteristik kewirausahaan sehingga dapat meningkatkan minat mahasiswa untuk berwirausaha serta memiliki kecintaannya pada dunia usaha atau kewirausahaan.

Minat mahasiswa yang tinggi pada kewirausahaan akan dapat menghasilkan pengusaha-pengusaha muda yang memiliki visi yang jelas pada masa depan, memiliki integritas, kreatif dan inovatif, mandiri, serta mampu mencari dan menangkap peluang bisnis baru dan penemuanpenemuan baru.

Masalah tingkat pengangguran terdidik atau tamatan perguruan tinggi akan dapat teratasi karena keluaran dari hasil pendidikan kewirausahaan telah mampu menciptakan lapangan kerja (job maker) untuk dirinya sendiri maupun untuk orang lain. Tamatan atau alumni perguruan tinggi tidak lagi sebagai pencari kerja (job seeker).

Pendidikan Kewirausahaan berpengaruh signifikan terhadap minat mahasiswa berwirausaha (Lestari dan Wijaya (2010). Pendidikan kewirausahaan dapat dilakukan dengan menggunakan metode pengajaran, kurikulum, kompetensi 
dosen, dan lamanya waktu belajar (Lestari dan Wijaya (2010).

Dalam penelitian ini variabel Pendidikan Kewirausahaan menggunakan dimensi : kurikulum kewirausahaan, metode pengajaran, kompetensi dosen, lamanya waktu belajar, dan praktek kewirausahaan.

Didalam suatu organisasi motivasi adalah suatu faktor yang amat penting dan menentukan, karena berhasil tidaknya pencapaian tujuan organisasi tergantung pada ada tidaknya motivasi yang dilakukan oleh manajer atau pimpinan suatu organisasi atau perusahaan.

Untuk mempermudah pemahaman mengenai motivasi dibawah ini dikemukakan beberapa pengertian motivasi. Menurut Allen bahwa motivasi adalah pekerjaan yang dilakukan seorang manajer dalam memberi inspirasi, semangat dan dorongan kepada orang lain untuk mengambil tindakan, sedangkan Terry menyatakan bahwa motivasi adalah keinginan yang terdapat pada seseorang individu yang merangsangnya untuk melakukan tindakan-tindakan (Nurmansyah, 2011:124).

Kegiatan motivasi adalah paling erat hubungannya dengan manusia, karena tidak salah bila dikatakan bahwa masalah motivasi adalah masalah manusia dalam organisasi.

Menurut David Mc Clelland seorang Guru besar dari Harvard University menyatakan bahwa timbulnya perilaku karena dipengaruhi oleh kebutuhankebutuhan yang ada dalam diri manusia. Dalam konsepnya mengenai motivasi dalam diri individu terdapat tiga kebutuhan pokok yang mendorong perilakunya. Konsep motivasi ini lebih dikenal dengan Achievement Motivation Theory dan ada juga yang menyebutnya dengan Social Motives Theory.

Kebutuhan untuk berpretasi (the need for achievement/ $n$ Ach) merupakan kebutuhan untuk mencapai sukses, yang diukur berdasarkan standar kesempurnaan dalam diri seseorang. Kebutuhan ini berhubungan erat dengan pekerjaan dan mengarahkan perilaku pada usaha untuk mencapai prestasi tertentu. Atau dengan kata lain kebutuhan berperestasi adalah daya untuk mengatasi tantangan, kemajuan dan pertumbuhan. Kebutuhan berprestasi memberikan hasil dan tenaga yang lebih sehingga orang bekerja lebih baik dan lebih maju. Mereka bekerja karena keinginan untuk mendapatkan tantangan dan pelayan orang lain.

Kebutuhan untuk beraffiliasi (the need for affiliation/ $n$ Aff) merupakan kebutuhan untuk berhubungan dengan orang lain. Orang yang mempunyai kebutuhan ini akan bekerja lebih giat jika mereka disanjung dan dipuji mengenai sikap dan kerjasamanya yang bermanfaat dan akan mengutamakan teman koleganya. Kebutuhan ini mengarahkan perilaku untuk mengadakan hubungan secara akrab dengan orang lain.

Kebutuhan untuk berkuasa (the need for power/n Pow) merupakan kebutuhan untuk menguasai dan mempengaruhi orang lain. Kebutuhan ini menyebabkan orang yang bersangkutan kurang memperdulikan orang lain. Orang yang bermotivasi ini cenderung untuk mengambil resiko, tetapi juga dapat mempunyai kekuatan untuk membangun suatu kesuksesan suatu organisasi/lembaga. Hasil studi menunjukkan bahwa orang yang mempunyai motivasi ini dapat membentuk seseorang manajer yang baik sepanjang kekuasaan yang dimillikinya digunakan untuk organisasi/ lembaga dan bukan untuk pribadinya.

\section{METODE}

Populasi dalam penelitian ini adalah semua mahasiswa Universitas Lancang Kuning Pekanbaru yang telah mengikuti perkuliahan Kewirausahaan berjumlah sebanyak 13.342 orang yang berada pada semester 3 keatas. Untuk keefektifan penelitian ini, maka tidak semua jumlah populasi dijadikan obyek penelitian. Untuk itu akan diambil sampel dari jumlah populasi yang akan mewakili dari populasi tersebut. Adapun teknik pengambilan sampel yang dilakukan adalah convenience sampling. 
Penetapan jumlah sampel dilakukan dengan menggunakan formulasi Slovin diperoleh sampel sebanyak 100 orang(Ridwan dan Kuncoro, 2007). Pengumpulan data primer diperoleh langsung dari responden/sampel terpilih (mahasiswa) pada Universitas Lancang Kuning. Data yang dikumpulkan berkaitan dengan indikator variabel penelitian yaitu Pendidikan Kewirausahaan, Motivasi dan Minat Berwirausaha Mahasiswa Universitas Lancang Kuning Pekanbaru. Data dalam penelitian ini diperoleh dengan menggunakan data primer dan sekunder. Teknik analisis data dilakukan dengan regresi linier berganda dengan menggunakan alat bantu statistik berupa program SPSS

\section{HASIL}

Pengujian hipotesis penelitian dilakukan dengan pendekatan regresi linier berganda dengan menggunakan program SPSS. Hasil pengujian koefisien regresi menunjukkan hasil sebagai berikut Tabel 1. Hasil Pengujian Koefisien Regresi

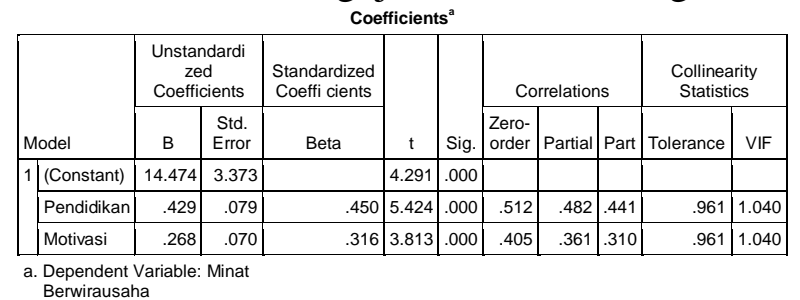

Berdasarkan Tabel 1 dapat ditarik suatu persamaan regresi linier Berganda. Minat Berwirausaha $=0,450 \quad$ Pendidikan Kewirausahaan $+0,316$ Motivasi + ei dimana persamaan ini memberikan makna yaitu :

1. Setiap penguatan karakter Pendidikan Kewirausahaan sebesar satu satuan, maka hal ini dapat meningkatkan Minat berwirausaha sebesar 0,450 satuan. Dengan asumsi bahwa variabel motivasi dianggap konstan.

2. Setiap penguatan karakter Motivasi sebesar satu satuan, maka hal ini dapat meningkatkan Minat mahasisw berwirausaha sebesar 0,316 satuan. Dengan asumsi bahwa variabel pendidikan kewirausahaan dianggap konstan.

Pengujian determinasi dimaksudkan untuk mengetahui seberapa besar persentase konstribusi variabel Pendidikan Kewirausahaan dan Motivasi dalam meningkatkan Minat Berwirausaha Mahasiswa. Pengujian dapat dilakukan dengan menggunakan model summary yang menunjukkan hasil seperti dapat dilihat pada Tabel 7 berikut ini :

Tabel 2. Hasil Pengujian Koefisien Determinasi

Model Summary

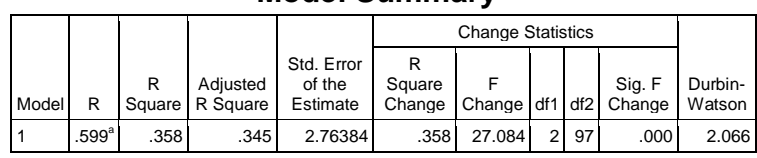

Pengaruh Pendididkan Kewirausahaan dan Motivasi secara bersama-sama berpengaruh sebesar 0,358 atau sebesar $35,80 \%$, sedangkan selisihnya sebesar $64,20 \%$ dipengaruhi oleh variabel lain diluar Pendidikan Kewirausahaan dan Motivasi. Hal ini menunjukkan bahwa tinggi rendahnya Minat Berwirausaha Mahasiswa cukup ditentukan dengan menerapkan Pendidikan Kewirausahaan dan Motivasi pada suatu lembaga pendidikan tinggi

\section{PEMBAHASAN}

\section{Pendidikan Kewirausahaan}

Hasil analisis deskriptif menunjukkan bahwa Pendidikan Kewirausahaan memiliki nilai yang tinggi oleh rata-rata mahasiswa Universitas Lancang Kuning dalam meningkatkan Minat Berwirausaha. Diantara sembilan indikator yang digunakan dalam penelitian ini, nilai yang paling rendah adalah indikator ketrampilan dalam praktek kewirausahaan, yang perlu ditingkatkan agar dapat memberikan ketrampilan dalam melakukan kegiatan kewirausahaan dengan memberikan ilmu pengetahuan, sikap dan perilaku yang dapat mendorong untuk berpikir kreatif dan inovatif, berani mengambil keputusan dan berani mengambil risiko, percaya diri, 
berorientasi pada hasil, memiliki jiwa kepemimpinan yang berani tampil beda, yang sangat diperlukan dalam mencari dan menangkap peluang bisnis baru dan penemuan-penemuan baru, atau melakukan sesuatu yang lama dengan cara yang baru.

Begitu pula halnya dengan waktu belajar perlu ditingkatkan dengan cara menambah waktu belajar dengan menambah SKS mata kuliah Kewirausahaan dan menambah 2 mata kuliah yaitu Mata kuliah Kewirausahaan I yang lebih menekankan pada teori dan mata kuliah Kewirausahaan II yang lebih menekankan pada praktek di kelas dan praktek diluar kelas dengan diskusi-diskusi serta mengunjungi usaha-usaha yang berhasil, dan bila memungkinkan diberi waktu belajar praktek di lapangan dan dibimbing oleh dosen-dosen yang memiliki kemampuan berwirausaha dan telah pernah menjalani usaha.

\section{Motivasi}

Hasil analisis deskriptif menunjukkan bahwa Motivasi memiliki nilai yang tinggi oleh rata-rata mahasiswa Universitas Lancang Kuning dalam meningkatkan Minat Berwirausaha. Diantara sembilan indikator yang digunakan dalam penelitian ini, nilai yang paling rendah adalah indikator hubungan dalam pekerjaan dari pada tugas yang ada pada pekerjaan. Hal ini perlu mendapatkan dukungan agar dapat lebih meningkatkan hubungan yang harmonis dan meningkatkan hubungan kerjasama diantara mahasiswa sehingga akan diperoleh informasi dan ide -ide untuk menciptakan dan menjalankan bisnis.

Sangat aktif menentukan arah kegiatan organisasi. Hal ini perlu dilakukan dengan memberikan motivasi bagaimana menentukan arah strategi organisasi untuk mencapai tujuan organisasi kemahasiswaan dan ini juga dapat membantu mahasiswa dalam meentukan arah kegiatan melakukan usaha kewirausahaan.

Lebih suka bekerjasama dengan orang lain dari pada bekerja sendiri. Hal ini perlu mendapatkan dukungan dengan menanamkan kebersamaan, karena dalam berusaha diperlukan kerjasama dengan berbagai pihak, dalam mendapatkan barang dan jasa serta menentukan jejaring usaha yang kesemuanya dapat terlaksana dengan baik bila pelaku usaha dapat saling bekerjasama, dan tidak jarang terjadi bahwa usaha dapat dibangun karena adanya kerjasama.

Mengambil tanggung jawab pribadi atas perbuatan yang dilakukan. Hal ini perlu mendapatkan dukungan dengan menumbuh kembangkan tanggung jawab atas apa yang dilakukan dengan membuat laporan pada setiap kegiatan yang dilakukan. Kebiasaan yang baik ini dapat menumbuhkan rasa tanggung jawab pada setiap individu bila kelak melakukan kegiatan usaha diamsa yang akan datang.

\section{Minat Berwirausaha}

Hasil penelitian menunjukkan bahwa secara umum tingkat Minat Berwirausaha mahasiswa Universitas Lancang Kuning masuk pada kategori sangat tinggi. Minat Berwirusaha mahasiswa Universitas Lancang Kuning sudah baik. Untuk meningkatkan Minat Berwirausaha Mahasiswa pihak Universitas harus memperbaiki sistem pemberian pendidikan Kewirausahaan dan diasuh oleh dosen yang memiliki pengetahuan kewirausahaan dan didukung pula dari pelaku-pelaku usaha yang berhasil serta mendatangkannya ke kampus untuk berbagi pengalamannya dalam menjalankan usahanya sehingga dapat menggugah mahasiswa untuk terjun kedunia wirausaha.

\section{Pengaruh Pendidikan Kewirausahaan Terhadap Minat Berwirausaha}

Untuk mengetahui seberapa signifikan pengaruh Pendidikan Kewirausahaan dan Motivasi dalam meningkatkan Minat Berwirausaha mahasiswa di lingkungan Universitas Lancang Kuning. Hal ini dapat dilakukan dengan menggunakan uji $\mathrm{t}$ (parsial), dengan cara membandingkan antara $\mathrm{t}$ hitung dengan $\mathrm{t}$ tabel, dan sig. $\mathrm{t}$ dengan $\alpha 5 \%$ atau 0,05 . Untuk mengetahui nilai $\mathrm{t}$ tabel dilakukan dengan cara $\mathrm{t}$ tabel $=$ $\alpha: \mathrm{dk}=\mathrm{n}-1$, dimana $\alpha=0,05$, dan $\mathrm{n}=100$. 
Sehingga dari t tabel dapat dilihat bahwa nilai t tabel adalah 1,98447 .

Pada Tabel 5.12 dapat diketahui bahwa nilai $\mathrm{t}$ hitung variabel Pendidikan Kewirausahaan 5.424 > t tabel $=1,98447$ dan Sig. t variabel Pendidikan kewirausahaan $0,000<0,05$. Dengan demikian dapat disimpulkan bahwa Pendidikan Kewirausahaan berpengaruh positif dan signifikan terhadap Minat Berwirausaha Mahasiswa Universitas Lancang Kuning. Hal ini sesuai dengan hasil penelitian Lestari dan Wijaya (2010) dengan judul Pengaruh Pendidikan Kewirausahaan Terhadap Minat Berwirausaha Mahasiswa di STIE MDP, STMIK MDP, dan STIE MDP Musi Palembang yang menyatakan terdapat pengaruh Pendidikan Kewirausahaan Terhadap Minat Mahasiswa Berwirausaha. Semakin ditingkatkan Pendidikan Kewirausahaan kepada mahasiswa Universitas lancang Kuning, maka akan dapat meningkatkan Minat Berwirausaha Mahasiwa, demikian pula sebaliknya.

\section{Pengaruh Motivasi Terhadap Minat Berwirausaha}

Variabel Motivasi berpengaruh sebesar 0,316 atau sebesar 31,60\% terhadap Minat Berwirausaha mahasiswa Universitas Lancang Kuning. Nilai t htiung variabel Motivasi 3,813 > t tabel 1,98447 dan Sig. variabel motivasi sebesar $0,000<0,05$. Dengan demikian dapat disimpulkan bahwa Motivasi berpengaruh positif dan signifikan terhadap Minat Berwirausaha Mahasiswa Universitas Lancang Kuning. Hal ini sesuai dengan hasil penelitian yang dilakukan oleh Mahesa dan Rahardja (2012) dengan judul Analisis Faktor-Faktor Motivasi Yang Mempengaruhi Minat Berwirausaha Mahasiswa yang menyatakan bahwa Motivasi berpengaruh terhadap Minat Berwirausaha mahasiswa Universitas Lancang Kuning. Dengan Semakin ditingkatkan motivasi kepada mahasiswa Universitas lancang Kuning, dapat meningkatkan Minat Berwirausaha Mahasiswa, demikian pula sebaliknya. Hal ini sejalan dengan pemikiran McClelland
(M.L. Jhingan, 2012:430) mengajukan suatu teori yang didasarkan pada hasil penelitiannya bahwa kewirausahaan pada akhirnya tergantung pada motivasi prestasi, kesadaran untuk mengerjakan dan mendapatkan sesuatu.

\section{Pengaruh \\ Pendidikan \\ Kewirausahaan dan Motivasi Terhadap Minat Berwirausaha}

Nilai $F$ hitung yang diperoleh dari hasil uji simultan (Uji F) sebesar $27.084>\mathrm{F}$ tabel $=3,10$ dan nilai Sig. $F=0,000<$ 0,05 . Hal ini memberikan makna bahwa Pendidikan Kewirausahaan dan Motivasi secara simultan berpengaruh signifikan terhadap Minat Berwirausaha pada mahasiswa Universitas Lancang Kuning. Penerapan Pendidikan Kewirausahaan dan Motivasi secara simultan dapat efektif dalam meningkatkan Minat Berwirausaha Mahasiswa Universitas Lancang Kuning. Untuk mengetahui seberapa signifikan pengaruh Pendidikan Kewirausahaan dan Motivasi dalam meningkatkan Minat Berwirausaha mahasiswa di lingkungan Universitas Lancang Kuning. Hal ini dapat dilakukan dengan menggunakan uji $t$ (parsial), dengan cara membandingkan antara $\mathrm{t}$ hitung dengan $\mathrm{t}$ tabel, dan sig. $\mathrm{t}$ dengan $\alpha 5 \%$ atau 0,05 . Untuk mengetahui nilai $\mathrm{t}$ tabel dilakukan dengan cara $\mathrm{t}$ tabel $=$ $\alpha: \mathrm{dk}=\mathrm{n}-1$, dimana $\alpha=0,05$, dan $\mathrm{n}=100$. Sehingga dari $t$ tabel dapat dilihat bahwa nilai t tabel adalah 1,98447 .

Pendidikan Kewirausahaan dan Motivasi secara simultan berpengaruh positif dan signifikan terhadap Minat Berwirausaha mahasiswa Universitas Lancang Kuning. Tetapi bila dilihat bahwa t hitung Pendidikan Kewirausahaan lebih besar dari pada t hitung Motivasi, demikian pula bila dilihat pada Tabel 5.12 dimana Pendidikan Kewirausahaan berpengaruh 0,450 atau sebesar $45 \%$ terhadap Minat Berwirausaha mahasiswa Universitas Lancang Kuning, sedangkan Variabel Motivasi berpengaruh sebesar 0,316 atau sebesar 31,60 \% terhadap Minat Berwirausaha mahasiswa Universitas

p.ISSN: $2407-800 X \quad$ e.ISSN: $2541-4356$ 
Lancang Kuning. Dengan demikian dapat disimpulkan bahwa Pendidikan Kewirausahaan lebih besar atau lebih dominan pengaruhnya dari pada Motivasi dalam mempengaruhi Minat Berwirausaha mahasiswa Universitas Lancang Kuning. Dari itu dalam pelaksanaannya dapat dilakukan secara bersamaan dan dapat pula dilakukan secara bergantian yang disesuaikan dengan situasi dan kondisi yang ada, namun demikian untuk meningkatkan Minat Berwirausaha Mahasiswa di lingkungan Universitas Lancang Kuning perlu memberikan porsi yang lebih besar pada Pendidikan kewirausahaan agar dapat lebih efektif dan untuk mendapatkan hasil yang lebih baik.

\section{SIMPULAN}

Berdasarkan hasil temuan penelitian yang dilakukan dapat ditarik beberapa kesimpulan sebagai berikut: Pendidikan Kewirausahaan berpengaruh positif dan signifikan terhadap Minat Berwirausaha mahasiswa Universitas Lancang Kuning. Pengaruh Pendidikan Kewirausahaan Terhadap Minat Berwirausaha mahasiswa dkatakan sedang dimana pengaruhnya sebesar $45 \%$. Hal ini disebabkan karena waktu belajar dan berdiskusi serta praktek di luar kelas yang diterima mahasiswa masih dirasakan kurang.

Motivasi berpengaruh secara positif dan signifikan terhadap Minat Berwirausaha mahasiswa Universitas Lancang Kuning. Pengaruh Motivasi Kewirausahaan Terhadap Minat Berwirausaha mahasiswa dkatakan sedang dimana pengaruhnya sebesar $31,60 \%$. Hal ini disebabkan karena mahasiswa kurang memperhatikan kerjasama dengan orang lain, kurang dapat menentukan arah kegiatan, kurangnya tanggung jawab pribadi atas perbuatan yang dilakukan.

Pendidikan Kewirausahaan dan Motivasi secara Simultan berpengaruh positif dan signifikan terhadap Minat Berwirausaha mahasiswa Universitas Lancang Kuning. Pengaruh Pendidikan Kewirausahaan dan Motivasi Terhadap
Minat Berwirausaha Mahasiswa universitas Lancang Kuning sebesar 35,80 \% dan dapat dikatakan berpengaruh cukup/sedang. Hal ini disebabkan karena menjadi wirausaha masih menjadi pilihan terakhir bagi mahasiswa Universitas Lancang Kuning setelah menjadi pegawai negeri (Aparatur Sipil Negara) dan pegawai swasta. Berdasarkan hasil tanggapan responden bahwa setelah menamatkan pendidikannya berkeinginan menjadi Pegawai negeri sebanyak $30 \%$, dan yang ingin menjadi pegawai swasta sebanyak $21 \%$, dan menjadi wirausaha sebanyak $47 \%$. Walaupun mahasiswa yang berminat menjadi wirausaha lebih besar, tetapi penggabungan mahasiswa yang berminat menjadi PNS dan Pegawai swasta sebanyak $53 \%$ lebih besar dari pada menjadi Wirausaha.

\section{DAFTAR RUJUKAN}

Direktorat Kelembagaan Dikti, 2009, Pedoman Program Mahasiswa Wirausaha Bagi Kopertis dan PTS, Jakarta.

Harefa, Andrias \& Siadari, Eben Ezer, 2006, The Ciputra Way, PT Elex Media Komputindo, Jakarta.

Jhingan, ML., 2012, Ekonomi Pembangunan dan Perencanaan, Terj., Rajawali Pers, Jakarta.

Kasmir, 2006, Kewirausahaan, RajaGrafindo Persada, Jakarta.

Lestari, Retno Budi, dan Wijaya, Trisnadi, 2010, Pengaruh Pendidikan Kewirausahaan Terhadap Minat Berwirausaha Mahasiswa di STIE MDP, STMIK MDP, dan STIE MUSI Palembang.

Mahesa, Aditya Dion, dan Rahardja, Edy., Analisis Faktor-Faktor Motivasi Yang 
Mempengaruhi Minat Berwirausaha, Diponegoro Journal Of Management, Volume 1, Nomor 1, Tahun 2012.

Nurmansyah, 2011, Manajemen Sumber Daya Manusia, Unilak Press, Pekanbaru.

Putra, Rano Aditya, 2012, Faktor-Faktor Penentu Minat Mahasiswa Manajemen

Untuk Berwirausaha (Studi Fakultas Ekonomi Universitas Negeri Padang), Jurnal Manajemen, Volume 01, Nomor 01, Sepetember 2012.

Segal, Gerry, Borgia and Jerry Schoenfeld, 2005, The Motivation To Become An Entrepreneur, International Journal of Entrepreneurial Behavior \& Research, Vol. 11, No. 1, Emerald Group Publishing Limited, USA.
Siregar, Syofian, 2014, Statistik Parametrik Untuk Penelitian Kuantitatif, Bumi Aksara, Jakarta.

Sugiono, 2006, Metode Penelitian, Alfabeta, Bandung

Siswoyo, H. Bambang Banu, 2009, Pengembangan Jiwa Kewirausahaan di Kalangan Dosen dan Mahasiswa, Jurnal Ekonomi Bisnis, Tahun 14, Nomor 2, Juli 2009, ISSN : 0853-7283

Susanto, Adi, 2006, Kewirausahaan, Ghalia Indonesia, Jakarta.

Suryana, 2006, Kewirausahaan, Salemba, Jakarta.

Umar, Husin, 2009, Riset SDM dan Perilaku Organisasi, Ghalia Indonesia, Jakarta.

Zimmerer, 2008, Kewirausahaan \& Manajemen Usaha Kecil 1\&2, Salemba, Jakarta. 